\title{
Preparation of Dried Vegetarian Soup Supplemented with Some Legumes
}

\author{
Amal M. H. Abdel-Haleem, Azza A. Omran* \\ Department of Crops Technology Research, Food Technology Research Institute, Agricultural Research Center, \\ Giza, Egypt \\ Email: azzaa omran@yahoo.com
}

Received 8 October 2014; revised 23 November 2014; accepted 11 December 2014

Copyright $@ 2014$ by authors and Scientific Research Publishing Inc.

This work is licensed under the Creative Commons Attribution International License (CC BY).

http://creativecommons.org/licenses/by/4.0/

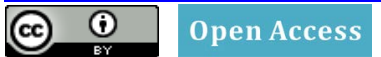

\section{Abstract}

The present work was aimed to prepare dried vegetarian soup supplemented with some legumes. Potatoes, hull-less barley flour, carrot, tomatoes, onion, garlic, salt, black pepper, coriander and cumin (served as $F_{1}$ ) were used in combination with lentil, green pea and chickpea to formulate $F_{2}$, $F_{3}$, and $F_{4}$, respectively. Chemical, physical, rheological and sensory evaluation was performed. The results indicated that supplementation with legumes significantly enhanced the nutritional characteristics, where the dried vegetarian soup mixtures had reasonable amounts of the required nutrients particularly, protein, carbohydrates, fats, Fe and $\mathrm{Zn}$ with good in vitro protein digestibility and mineral availability. Moisture content and water activity predicted the extended shelf-life and stability of the dried soup mixtures. The four resultant soup samples $F_{1}, F_{2}, F_{3}$ and $F_{4}$ had a noticeable viscosity pattern characterized by a non-Newtonian pseudoplastic flow behavior. Supplementation with legumes significantly $(p \leq 0.05)$ affects taste, color, flavor attributes and overall acceptability of the resultant soup samples. But, it had no significant effect on thickness and appearance. The results clearly demonstrated the usefulness of supplementing the dried vegetarian soup mixtures with legumes to enhance nutritional and technological quality of the resultant soup and lentil was the most valuable addition with the highest acceptability.

\section{Keywords}

Vegetarians Soup, Legumes, Nutritional Quality, Physical Characteristics Rheological Properties, Sensory Quality Attributes

\section{Introduction}

The frantic rhythm of modern life and the increase in the number of people who live alone have determined

*Corresponding author. 
changes in food preparation and in the habits of consumption. Less time is available for a cook to make food. In this consequence, the rapid progress of the ready-oven food technology and its products has to be mentioned. Dried soups play an important role in the nutrition of people because they fulfill present and future social consumer requirements [1].

The advantages of the dehydrated foods, particularly, dry soup mixes could be as a protection from enzymatic and oxidative spoilage and flavor stability at room temperature over long periods of time (6 - 12 months). Also, they do not need refrigerator and had quite nutritive value, particularly as a source of protein. In addition, they are ready for reconstitution in a short time for working families, hotels, hospitals, restaurants and institutional use as well as to military rations. Moreover, they exert light weight for shipping and availability at all time of the year [2]-[5].

It is well known that the good quality and reasonable ratio of dehydrated soup depend on variety and functional properties of supplemented individuals [6]. A balance of nutrients may be obtained by including whole cereals, vegetables, pulses and milk products, etc. Such these diets supply a large proportion of our energy needed, carbohydrate, protein, dietary fiber, amino acids and minerals [7]. Also, functional ingredients can be easily incorporated into soup powders to provide health benefits [8]. For example, cereal proteins are generally deficient in some essential amino acids, to augment the protein quality of cereal based foods, the concept of cereal-legume complementation by blending cereal and legume flour can be applied [4] [9] [10].

As the formulation and development of nutritious complementary foods from locally and readily available raw materials have received a lot of attentions, the present research work aimed to prepare and supplement dried vegetarian soup mixtures with some legumes and evaluating their chemical, physical, rheological and sensorial properties to assess the nutritional and technological quality of the resultant mixtures and soups.

\section{Materials and Methods}

\subsection{Raw Materials and Ingredients}

Hull-less barley, green pea, chick pea, lentil, potatoes, tomatoes, carrot, onion, garlic, black pepper, coriander, salt and cumin were obtained from local market in Cairo, Egypt.

\subsection{Chemicals}

Pepsin, pancreatin, $\alpha$-amylase and lipase were obtained from Sigma-Aldrich Chemical Co., St. Louis, USA. Bile extract from Win Lab Laboratory chemicals reagents, Mumbai, India. All other chemicals used were of analytical reagent grade.

\subsection{Preparation of Raw Materials}

Potato and carrot samples were sorted, washed, peeled and sliced in cubic form and blanched in hot water at $95^{\circ} \mathrm{C}$ for 5 min then washed in cold water then hot air flow drying were performed at $65^{\circ} \mathrm{C}$ in the first four hours and then reduced to $50^{\circ} \mathrm{C}$ till completely drying. Then milled and sieved (315 micron) into powdered form. Tomatoes were sliced then dried and milled as the above mentioned method. Lentil, green pea and chickpea were subjected to some technological treatments before formulation as illustrated in Figure 1. Hull-less barley grains were laboratory milled to a fine powder using a hammer mill following by grinding into flour and sieving through $315 \mu \mathrm{m}$ sieve.

\subsection{Formulation of the Dried Vegetarian Soup Mixtures}

The prepared samples were seasoned with dried onion, garlic, coriander, black pepper, cumin and salt then mixed to formulate four dried vegetarian soup mixtures (three replicates for each formula) namely $F_{1}, F_{2}, F_{3}$ and $\mathrm{F}_{4}$ as shown in Table 1 . The obtained mixtures were packed into polyethylene bags and kept at $-20^{\circ} \mathrm{C}$ for further analysis.

\subsection{Chemical Analysis}

\subsubsection{Proximate Analysis of the Dried Vegetarian Soup Mixtures}

Moisture, protein, fat, crude fiber, ash, iron (Fe) and zinc ( $\mathrm{Zn}$ ) contents of the dried vegetarian soup mixtures were determined according to the methods of AOAC [11]. 


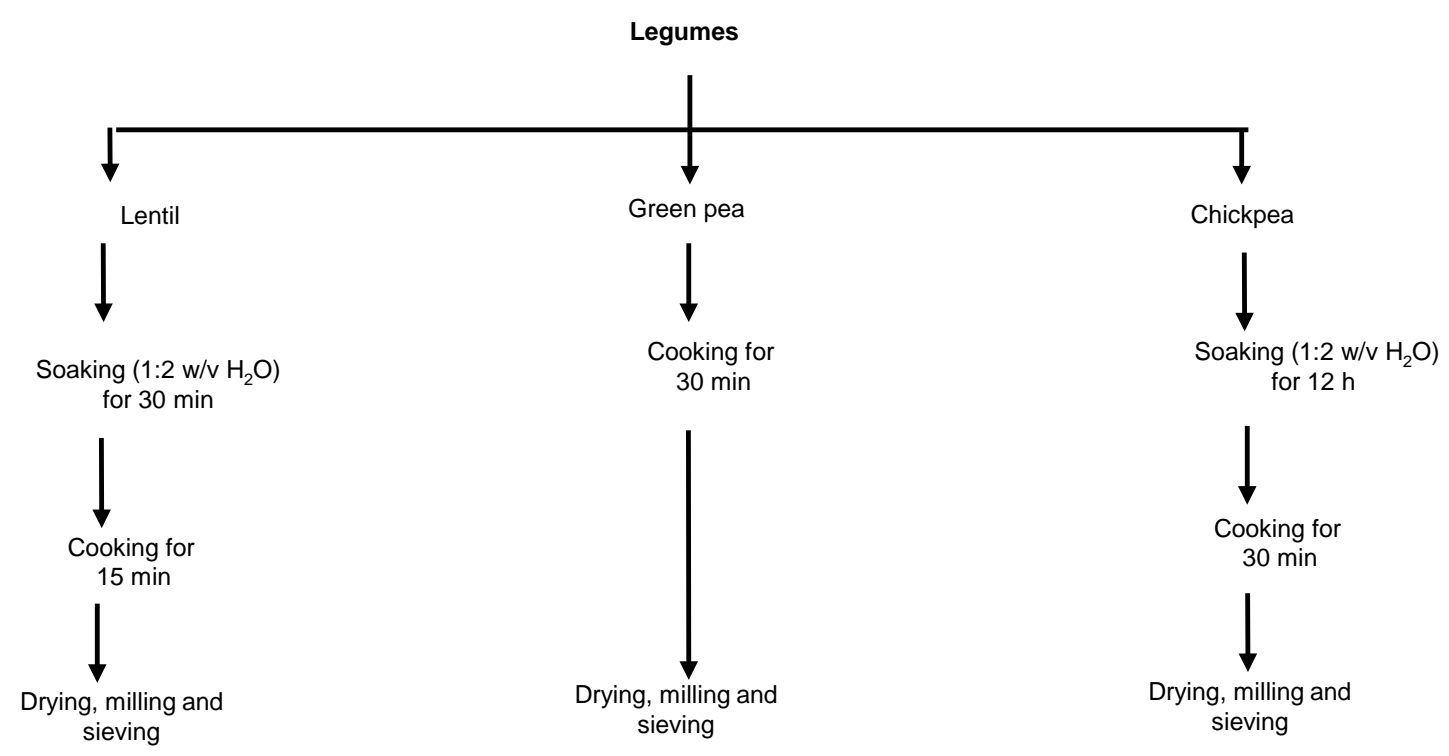

Figure 1. Some technological treatments for legumes before formulation.

Table 1. Formula of the dried vegetarian soup mixtures (g/100g).

\begin{tabular}{ccccc}
\hline Ingredients & Potato and Barley Formula $\left(F_{1}\right)$ & Lentil Formula $\left(F_{2}\right)$ & Green Pea Formula $\left(F_{3}\right)$ & Chickpea Formula $\left(F_{4}\right)$ \\
\hline Lentil & - & 35.0 & - & - \\
Green Pea & - & - & 35.0 & - \\
Chickpea & - & - & - & 35.0 \\
Potato & 39.50 & 22.0 & 22.0 & 18.0 \\
Barley & 35.50 & 18.0 & 18.0 & 5.0 \\
Tomato & 5.0 & 5.0 & 5.0 & 14.0 \\
Carrot & 14.0 & 14.0 & 14.0 & 1.20 \\
Onion & 1.20 & 1.20 & 1.20 & 0.75 \\
Garlic & 0.75 & 0.75 & 0.75 & 3.0 \\
Salt & 3.0 & 3.0 & 3.0 & 0.35 \\
Black Pepper & 0.35 & 0.35 & 0.35 & 0.35 \\
Cumin & 0.35 & 0.35 & 0.35 & 0.35 \\
Coriander & 0.35 & 0.35 & 0.35 & 100 \\
Total & 100.0 & 100.0 & 100.0 & \\
\hline
\end{tabular}

\subsubsection{Total Calories of the Dried Vegetarian Soup Mixtures}

Total calories of the dried vegetarian soup mixtures were calculated by the formula of James [12] as follows:

$$
\text { Total calories }=\text { Fat } \times 9+\text { Protein } \times 4+\text { Total carbohydrate } \times 4
$$

\subsubsection{Determination of in Vitro Protein Digestibility (IVPD)}

The IVPD of the dried vegetarian soup mixtures was determined according to the method of Akeson and Stahmann [13]. After enzymatic digestion of samples with pepsin $\left(37^{\circ} \mathrm{C} / 3 \mathrm{~h}\right)$ and pancreatin $\left(37^{\circ} \mathrm{C} / 24 \mathrm{~h}\right)$, the protein in the resultant supernatant was estimated using the Kjeldahl method according to AOAC [11]. The percentage of protein digestibility was calculated by the ratio of protein in supernatant to protein in sample as the 
following equation:

$$
\text { In vitro protein digestibility }(\%)=\frac{\mathrm{N} \text { in supernatant }-\mathrm{N} \text { in Blank }}{\mathrm{N} \text { in sample }} \times 100
$$

$\mathrm{N}=$ Nitrogen

\subsubsection{In Vitro Iron (Fe) and Zinc (Zn) Availability}

The in vitro availability of iron and zinc of the dried soup mixtures was determined according to the method of Kiers et al. [14]. Triplicate samples (5 g) were subjected to simulated gastro-intestinal enzymatic degradation, using $\alpha$-amylase lipase, pepsin, and pancreatic solutions subsequently. After digestion and centrifugation, the amounts of soluble Fe and $\mathrm{Zn}$ in the supernatant were read against blank by using the Perkin Elmer (Model 3300, USA) Atomic Absorption Spectrophotometer. Percentage of soluble mineral was calculated as the following equation:

$$
\text { Availability of Fe or } \mathrm{Zn}(\%)=\frac{\text { Fe or } \mathrm{Zn} \text { in supernatant }- \text { Fe or Zn in blank }}{\text { Fe or } \mathrm{Zn} \text { in undigested sample }} \times 100
$$

\subsection{Physical Characteristics of Samples}

\subsubsection{Water Activity $\left(a_{\mathrm{w}}\right)$}

The water activity $\left(a_{\mathrm{w}}\right)$ or of the dried vegetarian soup mixtures was measured using Rotronic Hygrolab 3 CH-8303, Switzerland as mentioned by Cadden [15].

\subsubsection{Color Measurement of the Dried Vegetarian Soup Mixtures}

External color of the dried vegetarian soup mixtures was measured according to the method outlined by Mc Gurie [16] using a hand-held Chromameter (model CR-400, Konica Minolta, Japan).

\subsection{Rheological Properties of the Resultant Soup Samples}

Rheological parameters (viscosity and shear rate) of dried vegetarian soup samples were measured according to Brookfield manual [17] by using Brookfield Engineering labs DV-III Ultra Rheometer. The sample was placed in a small sample adapter and a constant temperature water bath was used to maintain the desired temperature. The viscometer was operated between 10 and $60 \mathrm{rpm}$. Viscosity and shear rate data were obtained directly from the instrument, the SC4-21 spindle was selected for the measurement. Rheological measurements were made at the resultant soup samples $\left(\mathrm{F}_{1}, \mathrm{~F}_{2}, \mathrm{~F}_{3}\right.$ and $\left.\mathrm{F}_{4}\right)$ and controlled at room temperature $\left(25^{\circ} \mathrm{C} \pm 1^{\circ} \mathrm{C}\right)$.

\subsection{Rehydration Ratio (RR)}

Rehydration ratio was performed according to Krokida and Marinos-Kouris [18]. A given (2 g) of the dried vegetarian soup mixtures were rehydrated in $20 \mathrm{ml}$ distilled in a water bath at constant temperature, which was agitated at constant speed (100 rpm). The samples were taken from the bath after 10 minutes and were weighted after being blotted with tissue paper in order to remove the excess solution. Rehydration ratio was defined as the ratio of weight of rehydrated samples to the dry weight of the sample.

\subsection{Organoleptic Evaluation of the Resultant Soup Samples}

The resultant soup samples were organolyptically evaluated after dissolving in hot water ( $10 \mathrm{~g}$ dried vegetarian soup mixtures/65 ml water) for its sensory characteristics, i.e., taste, flavor, color, thickness and appearance, dissolution rate and overall acceptability. The evaluation was carried out by ten panelists according to the method of Wang et al. [19].

\subsection{Statistical Analysis}

The obtained data from chemical and rheological properties and sensory evaluation were exposed to analysis of variance. Duncan's multiple range tests at $(\mathrm{p} \leq 0.05)$ level was used to compare between means. 


\section{Results and Discussion}

\subsection{Nutritional Quality of the Dried Vegetarian Soup Mixtures}

Pulse crops include lentil, chickpea and peas are an excellent source of protein, carbohydrates, and fiber, and provide many essential vitamins and minerals. Their highly nutritional properties have been associated with many beneficial health-promoting properties [20]. Legumes are used in combination with cereals in food preparations as a cheap and concentrated source of proteins [9].

Table 2 exhibits the nutritional characteristics of the dried vegetarian soup mixtures on dry weight basis. As expected, supplementation with legumes significantly increased fat and protein contents of the dried vegetarian soup mixtures. But, it significantly decreased total carbohydrates contents.

The significant increase in fat was pronounced more on $\mathrm{F}_{4}$. Meanwhile, the increase in protein was pronounced more on $F_{1}$. While, supplementation with green pea recorded higher increase in ash and crude fiber contents. Our present findings are in accordance with Adsule [21] who mentioned that lentil is high in protein especially rich in lysine and leucine, low in fat, and is an excellent source of dietary fiber and complex carbohydrates. And with Shah et al. [22] who stated that chickpea is a good source of protein and improves the nutritive value of cereal-based diet. Also, Jokanović et al. [23] approved that green peas have a nutritionally favorable composition in respect to macronutrients: low fat, high fiber and protein content.

Considering Dietary Reference Intakes (DRI) [24] of total fat, each $100 \mathrm{~g}$ dried vegetarian soup mixtures provide $9.80 \%, 10.97 \%, 11.60 \%$ and $17.77 \%$ from daily intake of fat (based on $30 \mathrm{~g}$ fat/day) from $\mathrm{F}_{1}, \mathrm{~F}_{2}, \mathrm{~F}_{3}$ and $\mathrm{F}_{4}$ respectively.

Regarding DRI of protein, each $100 \mathrm{~g}$ dried vegetarian soup mixtures provide $16.22 \%$, 33.89\%, 33.78\% and $30.65 \%$ from daily intake of protein for female aged 19 - $50 \mathrm{y}$ with $55 \mathrm{~kg}$ bwt (based on $46 \mathrm{~g}$ protein/ day) from $\mathrm{F}_{1}, \mathrm{~F}_{2}, \mathrm{~F}_{3}$ and $\mathrm{F}_{4}$ respectively. And $13.32 \%, 27.84 \%, 27.75 \%$ and $25.18 \%$ from daily intake of protein for male aged 19 - 50 y with $65 \mathrm{~kg}$ bwt (based on $56 \mathrm{~g}$ protein/day) from $\mathrm{F}_{1}, \mathrm{~F}_{2}, \mathrm{~F}_{3}$ and $\mathrm{F}_{4}$, respectively.

Dietary sources of essential elements are important for correct physiological functions of the human body [1]. A deficient intake of certain minerals can produce diseases and lead to abnormal development [25]. Iron serves metabolic and enzymatic functions [26]. Zinc, is essential for normal growth, development of the immune response and participating as a cofactor for more than 300 enzymes [27] [28].

Data in Table 2 indicated that supplementation with legumes significantly enhanced Fe content in the dried vegetarian soup mixtures. Where, $F_{4}$ recorded the highest content followed by $F_{3}$. In addition, supplementation with chickpea and green pea significantly enhanced Zn content, but supplementation with lentil had no significant increase on $\mathrm{Zn}$ content compared to $\mathrm{F}_{1}$.

Roy et al. [20] reviewed that chickpea is an excellent source of minerals, especially calcium, phosphorous, iron, and magnesium. Also, DellaValle et al. [29] stated that lentils are an excellent source of micronutrients, including Fe. In addition, Jokanović [23] mentioned that with respect to the micronutrient of green peas, comparing to other vegetables, they're rich in iron.

The reference daily intakes for iron (18 mg) and zinc (15 mg) have been established by Mindel [30]. Accordingly, each $100 \mathrm{~g}$ dried vegetarian soup mixtures provide (25.67\%, 15.53\%), (28.11\%, 16.67\%), (29.72\%, $18.20 \%$ ) and (34.61\%, 18.13\%) from daily intake of $\mathrm{Fe}$ and $\mathrm{Zn}$ from $\mathrm{F}_{1}, \mathrm{~F}_{2}, \mathrm{~F}_{3}$ and $\mathrm{F}_{4}$ respectively.

From the calculated data of the caloric value it could be noticed that supplementation with legumes significantly increased the caloric value of the dried vegetarian soup mixtures. Considering the References Daily

Table 2. Nutritional characteristics of the dried vegetarian soup mixtures on dwt ${ }^{*}$.

\begin{tabular}{ccccccccc}
\hline Samples & Fats (\%) & $\begin{array}{c}\text { Ash } \\
\mathbf{( \% )}\end{array}$ & $\begin{array}{c}\text { Protein } \\
\mathbf{( \% )}\end{array}$ & $\begin{array}{c}\text { Crude Fiber } \\
\mathbf{( \% )}\end{array}$ & $\begin{array}{c}\mathbf{T C}^{* *} \\
\mathbf{( \% )}\end{array}$ & $\begin{array}{c}\mathbf{F e} \\
(\mathbf{m g} / \mathbf{1 0 0 g})\end{array}$ & $\begin{array}{c}\text { Zn } \\
(\mathbf{m g} / \mathbf{1 0 0 g})\end{array}$ & $\begin{array}{c}\text { Caloric Value } \\
\mathbf{K c a l} / \mathbf{1 0 0 g}\end{array}$ \\
\hline $\mathrm{F}_{1}$ & $2.94 \pm 0.05^{\mathrm{d}}$ & $6.82 \pm 0.37^{\mathrm{a}}$ & $7.46 \pm 0.56^{\mathrm{c}}$ & $1.74 \pm 0.04^{\mathrm{bc}}$ & $82.78 \pm 0.99^{\mathrm{a}}$ & $4.62 \pm 0.02^{\mathrm{d}}$ & $2.33 \pm 0.01^{\mathrm{b}}$ & $387.42 \pm 0.30^{\mathrm{d}}$ \\
$\mathrm{F}_{2}$ & $3.29 \pm 0.08^{\mathrm{c}}$ & $6.16 \pm 0.19^{\mathrm{b}}$ & $15.59 \pm 0.01^{\mathrm{a}}$ & $1.68 \pm 0.01^{\mathrm{c}}$ & $74.96 \pm 0.28^{\mathrm{b}}$ & $5.06 \pm 0.01^{\mathrm{c}}$ & $2.50 \pm 0.01^{\mathrm{b}}$ & $391.81 \pm 0.20^{\mathrm{b}}$ \\
$\mathrm{F}_{3}$ & $3.48 \pm 0.08^{\mathrm{b}}$ & $6.71 \pm 0.04^{\mathrm{a}}$ & $15.54 \pm 0.02^{\mathrm{a}}$ & $4.39 \pm 0.05^{\mathrm{a}}$ & $74.27 \pm 0.14^{\mathrm{b}}$ & $5.35 \pm 0.03^{\mathrm{b}}$ & $2.73 \pm 0.10^{\mathrm{a}}$ & $390.56 \pm 0.20^{\mathrm{c}}$ \\
$\mathrm{F}_{4}$ & $5.33 \pm \pm 0.09^{\mathrm{a}}$ & $6.28 \pm 0.01^{\mathrm{b}}$ & $14.10 \pm 0.05^{\mathrm{b}}$ & $1.86 \pm 0.12^{\mathrm{b}}$ & $74.29 \pm .15^{\mathrm{b}}$ & $6.23 \pm 0.07^{\mathrm{a}}$ & $2.72 \pm 0.10^{\mathrm{a}}$ & $401.53 \pm 0.10^{\mathrm{a}}$ \\
\hline
\end{tabular}

"dwt = dry weight. ${ }^{* *}$ TC: Total carbohydrate was calculated by difference. Values are meaning of three replicates \pm SD, number in the same column followed by the same letter is not significantly different at 0.05 level. 
Intake (RDI), $\mathrm{F}_{1}, \mathrm{~F}_{2}, \mathrm{~F}_{3}$ and $\mathrm{F}_{4}$ will provide $16.14 \%, 16.33 \%, 16.27 \%$ and $16.73 \%$ respectively, from the RDA of energy for female aged 19 - 50 y and $55 \mathrm{~kg}$ bwt (calculated as $2400 \mathrm{Kcal} / \mathrm{day})$. And 12.91\%, 13.06\%, 13.02\% and $13.38 \%$ respectively, from the RDA of energy (calculated as $3000 \mathrm{Kcal} /$ day) for male aged 19 - 50 y and 65 $\mathrm{kg}$ bwt (calculated as $3000 \mathrm{Kcal} /$ day) from $\mathrm{F}_{1}, \mathrm{~F}_{2}, \mathrm{~F}_{3}$ and $\mathrm{F}_{4}$ respectively.

Accordingly, the resultant soup could be considered as low caloric soup and could be incorporated into athletic or regimen diets. Spill [31] stated that consuming low-energy-dense vegetable soup could influence hunger, satiety, and energy intake. In adults, consuming soup as a first course has been shown to enhance satiety, reduce intake of the main course, and reduce overall energy intake at the meal.

From the above mentioned data about the nutritional characteristics, it could be demonstrated that the dried vegetarian soup mixtures had reasonable amounts of the required nutrients particularly protein, energy, fats, Fe and Zn.

\subsection{In Vitro Protein Digestibility (IVPD) and Fe and Zn Availability}

Protein digestibility is an important factor when assessing the protein quality and nutritional status of a food product [32].

Table 3 represents the in vitro protein digestibility (IVPD. Data showed that supplementation with legumes significantly increased IVPD compared to $\mathrm{F}_{1}$. IVPD in $\mathrm{F}_{2}, \mathrm{~F}_{3}$ and $\mathrm{F}_{4}$ ranged from $70.47 \%$ to $72.67 \%$, which were not significantly affected from each others. Our present findings are in accordance with Boye et al. [33] who reviewed that in vitro protein digestibility of lentil was $73.5 \%(\mathrm{w} / \mathrm{w})$. And with Clemente et al. [34] who stated that the IVPD of chickpea was ranged from $69.7 \%$ to $71.8 \%$ (w/w). Also, Gargallo et al. [35] estimated the in vitro protein digestibility of green peas and it was $72.57 \%$.

Considering the method of processing, before formulation, lentil, green pea and chickpea were subjected to some technological treatments (soaking and cooking) besides drying process as illustrated in Figure 1, these processing methods increase the IVPD.

Vijayaraghavan [36] stated that Processing of legumes increases the digestibility and enhances the aroma, sensory qualities and nutritional attributes. This is most likely by destroying heat labile protease inhibitors and by denaturing other protein globulins highly resistant to proteases in the native state [22].

To estimate the quality of a dietetic source of a given mineral, it is necessary to precisely define the amount of mineral available for absorption and utilization, i.e., its bioavailability [25]. The bioavailability of iron and zinc from foods is defined as the proportion of the iron and zinc that can be absorbed and utilized within the body [37].

The in vitro iron and zinc availability of the dried vegetarian soup mixtures are shown in Table 3. It could be noticed that the in vitro iron and zinc availability ranged between $26.11 \%-28.12 \%$ and $38.02 \%-45.54 \%$, respectively. $F_{1}$ exhibited the lowest in vitro iron and zinc availability. Supplementation with lentil and chickpea significantly increased in vitro iron and zinc availability compared to $\mathrm{F}_{1}$.

In contrast, supplementation with green pea had no significant effect on in vitro iron and zinc availability compared to $\mathrm{F}_{1}$.

To increase the in vitro iron and zinc availability, as illustrated in Figure 1 lentil, green pea and chickpea were subjected to soaking and cooking besides drying process.

In legume-based foods, the availability of iron and zinc for absorption is limited by the presence of antinutritional factors (ANF) [37]. With an absence of these inhibitors, zinc absorption can be greater than 50\% [38]. Food processing by heat generally alters the bioavailability of nutrients-both macro and micro. The digestibility

Table 3. In vitro protein digestibility (IVPD) and in vitro Fe and Zn availability of the dried vegetarian soup mixtures (\%).

\begin{tabular}{cccc}
\hline Samples & IVPD (\%) & Fe Availability (\%) & Zn Availability (\%) \\
\hline$F_{1}$ & $66.54 \pm 2.05^{\mathrm{b}}$ & $23.80 \pm 4.01^{\mathrm{b}}$ & $37.19 \pm 1.32^{\mathrm{b}}$ \\
$\mathrm{F}_{2}$ & $72.67 \pm 0.57^{\mathrm{a}}$ & $28.12 \pm 3.50^{\mathrm{a}}$ & $42.51 \pm 2.55^{\mathrm{a}}$ \\
$\mathrm{F}_{3}$ & $70.47 \pm 1.08^{\mathrm{a}}$ & $26.11 \pm 0.93^{\mathrm{ab}}$ & $38.02 \pm 1.00^{\mathrm{b}}$ \\
$\mathrm{F}_{4}$ & $71.78 \pm 0.02^{\mathrm{a}}$ & $27.48 \pm 0.37^{\mathrm{a}}$ & $45.45 \pm 1.45^{\mathrm{a}}$ \\
\hline
\end{tabular}

Values are meaning of three replicates $\pm \mathrm{SD}$, number in the same column followed by the same letter is not significantly different at 0.05 level. 
and hence absorption of micronutrients such as iron is believed to be improved upon heat processing; with the resultant softening of the food matrix, protein-bound iron is released, thus facilitating its absorption [39].

\subsection{Physical Characteristics of the Dried Vegetarian Soup Mixtures}

\subsubsection{Moisture Contents and Water Activity $\left(a_{w}\right)$ of the Dried Vegetarian Soup Mixtures}

Water has several effects on food stability, palatability, and overall quality. Moisture can affect the physical properties such as hardening or clotting in powder or powder product. Water as a plasticizer, has an additional effect on the shelf life of low-and intermediate-moisture foodstuffs [40]-[42].

Table 4 represents the moisture content (\%) and $a_{\mathrm{w}}$ of the dried vegetarian soup mixtures. By adding legumes, the moisture contents of the dried vegetarian soup mixtures varied as seen in Table 4.

$\mathrm{F}_{4}$ was recorded the maximal water content $\left(9.84 \pm 0.04^{\mathrm{a}}\right) \%$ in all investigated samples followed by $\mathrm{F}_{3}(9.51 \pm$ $\left.0.39^{\mathrm{ab}}\right) \%$. In contrast, $\mathrm{F}_{2}$ recorded the minimal water content $\left(8.51 \pm 0.10^{\mathrm{c}}\right) \%$. Hall [43] reported that the amount of water and degree of binding are affected by factors such as protein type, concentration, and number of exposed polar group, $\mathrm{pH}$, salt(s) and temperature. Luh and Woodroof [2] stated that when the moisture content of dehydrated food is below $8 \%$ microorganisms do not grow while when moisture content is above $18 \%$ some microorganisms may be reproduced gradually. In addition, El Wakeel [4] declared that when the moisture content of dried materials was less than $10 \%$ such materials are considered as more proper for keeping quality of soup ingredients.

The physicochemical state of water is related to water activity $a_{\mathrm{w}}$, which is a measure of water availability for the growth of various microorganisms. Water activity is a major issue in relation to chemical stability of dry food products and has already been identified as an intrinsic factor in determining shelf-life [41] [44]-[46].

From the same Table, all the given values of the $a_{\mathrm{w}}$ was measured at a temperature ranged from 32.60 up to $33.30^{\circ} \mathrm{C}$ and the data proved that supplementation with legumes significantly affected $a_{\mathrm{w}}$ values of the dried vegetarian soup mixtures. Where, there is no $a_{\mathrm{w}}$ higher than $\mathrm{F}_{4}\left(0.47 \pm 0.01^{\mathrm{a}}\right)$ followed by $\mathrm{F}_{3}\left(0.44 \pm 0.01^{\mathrm{b}}\right)$. In contrast, $\mathrm{F}_{2}$ recorded the lowest value $\left(0.38 \pm 0.01^{\mathrm{d}}\right)$ of $a_{w}$.

Reduction of $a_{w}$ often affects microbial growth, the predominant microbial culture and it increases shelf life as a result of the reduced availability of water for the microbial growth [47]. Almost all microbial activity is inhibited below $a_{\mathrm{w}}=0.6$, most fungi are inhibited below $a_{\mathrm{w}}=0.7$, most yeasts are inhibited below $a_{\mathrm{w}}=0.8$ and most bacteria below $a_{\mathrm{w}}=0.9$ [48]. Very low values of $a_{\mathrm{w}}$ are related to high lipid oxidation rates while between $a_{w}$ values of 0.2 and 0.4 , lipids have been suggested to have optimal stability and oxidation rates increase again with increasing $a_{\mathrm{w}}$ [45].

From the above mentioned data about moisture content and $a_{\mathrm{w}}$ it could predict the chemical stability (minimum oxidation velocity) and keeping safety and quality of the dried vegetarian soup mixtures (lower the moisture content by a foodstuff, the longer the shelf life). The most dried vegetarian soup mixtures exhibited the highest extended shelf-life and stability is lentil one $\left(\mathrm{F}_{2}\right)$ compared to $\mathrm{F}_{1}, \mathrm{~F}_{3}$ and $\mathrm{F}_{4}$.

Table 4. Moisture content and water activity $\left(a_{\mathrm{w}}\right)$ of the dried vegetarian soup mixtures.

\begin{tabular}{cccc}
\hline Samples & Moisture (\%) & Water Activity $\boldsymbol{a}_{\mathrm{w}}$ & Temperature $\left({ }^{\circ} \mathbf{C}\right)$ \\
\hline$F_{1}$ & $9.33 \pm 0.10^{\mathrm{b}}$ & $0.41 \pm 0.01^{\mathrm{c}}$ & 32.60 \\
$F_{2}$ & $8.51 \pm 0.10^{\mathrm{c}}$ & $0.38 \pm 0.01^{\mathrm{d}}$ & 32.80 \\
$F_{3}$ & $9.51 \pm 0.39^{\mathrm{ab}}$ & $0.44 \pm 0.01^{\mathrm{b}}$ & 32.94 \\
$F_{4}$ & $9.84 \pm 0.04^{\mathrm{a}}$ & $0.47 \pm 0.01^{\mathrm{a}}$ & 33.31 \\
\hline
\end{tabular}

Values are mean of three replicates \pm SD, number in the same column followed by the same letter is not significantly different at 0.05 level.

\subsubsection{Color of the Dried Vegetarian Soup Mixtures}

Color is one of the most important quality attributes of vegetable products [49]. Color measurements of the dried vegetarian soup mixtures are illustrated in Table 5 . Data in Table 5 indicated that supplementation with legumes significantly increased the lightness $(L)$ values of the dried vegetarian soup mixtures, where $\mathrm{F}_{4}$ recorded the highest value followed by $\mathrm{F}_{2}$. The redness $(a)$ values of the dried vegetarian soup mixtures significantly increased in $F_{2}$ and $F_{4}$ compared to $F_{1}$, but it significantly decreased in $F_{3}$, and this is may be due to the potential 
Table 5. Color of the dried vegetarian soup mixtures*.

\begin{tabular}{ccccccc}
\hline Samples & $\mathbf{L}$ & $\mathbf{a}$ & $\mathbf{b}$ & $\mathbf{c}$ & $\mathbf{h}$ & Color \\
\hline $\mathrm{F}_{1}$ & $79.80 \pm 0.02^{\mathrm{d}}$ & $6.41 \pm 0.01^{\mathrm{c}}$ & $25.83 \pm 0.03^{\mathrm{d}}$ & $26.61 \pm 0.11^{\mathrm{d}}$ & $76.06 \pm 0.06^{\mathrm{d}}$ & Orange Yellow \\
$\mathrm{F}_{2}$ & $83.99 \pm 0.01^{\mathrm{b}}$ & $6.92 \pm 0.02^{\mathrm{b}}$ & $32.38 \pm 0.10^{\mathrm{b}}$ & $33.11 \pm 0.01^{\mathrm{b}}$ & $77.94 \pm 0.04^{\mathrm{c}}$ & Orange Yellow \\
$\mathrm{F}_{3}$ & $82.44 \pm 0.04^{\mathrm{c}}$ & $2.39 \pm 0.01^{\mathrm{d}}$ & $30.55 \pm 0.15^{\mathrm{c}}$ & $30.64 \pm 0.04^{\mathrm{c}}$ & $85.53 \pm 0.03^{\mathrm{a}}$ & Yellow \\
$\mathrm{F}_{4}$ & $85.35 \pm 0.05^{\mathrm{a}}$ & $7.19 \pm 0.01^{\mathrm{a}}$ & $34.87 \pm 0.03^{\mathrm{a}}$ & $35.60 \pm 0.01^{\mathrm{a}}$ & $78.35 \pm 0.10^{\mathrm{b}}$ & Orange Yellow \\
\hline
\end{tabular}

* $\mathrm{L}$ (lightness with $\mathrm{L}=100$ for lightness, and L = zero for darkness), a [(chromaticity on a green $(-)$ to red (+)], b [(chromaticity on a blue $(-)$ to yellow $(+)$ ], c (color saturation), h [(hue angle where $0^{\circ}=$ red to purple, $90^{\circ}=$ yellow, $180^{\circ}=$ bluish to green and $270^{\circ}=$ blue scale. Values are mean of three replicates $\pm \mathrm{SD}$, number in the same column followed by the same letter are not significantly different at 0.05 level.

green color of the green pea. This is in turn alters the resultant color of $\mathrm{F}_{3}$ from orange yellow and it became yellow compared to $F_{1}, F_{2}$ and $F_{4}$. Regarding yellowness (b) values, supplementation with legumes significantly increased the yellowness of the dried vegetarian soup mixtures. Where, $F_{4}$ recorded the maximal $b$ value, in contrast, $\mathrm{F}_{3}$ recorded the minimal $\mathrm{b}$ value. Like yellowness value, color saturation value (c) of $\mathrm{F}_{4}$ was found to be the highest value. Besides, supplementation with green pea in $F_{3}$ had the highest hue angle values.

\subsection{Rheological Properties of the Dried Vegetarian Soup Mixtures and the Resultant Soup Samples}

\subsubsection{Viscosity of the Resultant Soup Samples}

Knowledge of the rheological behavior of foods during processing is valuable for process control and quality control purposes. Viscosity is an important characteristic of liquid foods in many areas of food processing. The relationship between viscosity and shear rate can be used to classify foods into Newtonian, non-Newtonian, pseudoplastic, dilatant, thixotropic and rheopectic. Such classification is known to be useful in processing, quality control, sensory evaluation, and structural analysis [48] [50] [51].

The relationship between shear rate $\left(\mathrm{S}^{-1}\right)$ and values of the viscosity (cP) of the dried vegetarian soup supplemented with legumes could be illustrated in Figure 2. From the given data in Figure 2, it seems that the apparent viscosity (cP) of soup samples decreased as shear rate increased. This simply means that the four dried vegetarian soups; $F_{1}, F_{2}, F_{3}$ and $F_{4}$ had a noticeable apparent viscosity pattern could be characterized within the non-Newtonian pseudoplastic flow behavior. The same Figure depicts that $F_{1}$ apparent viscosity pattern recorded the highest values (4410 - $1188.33 \mathrm{cP})$ compared to $\mathrm{F}_{2}, \mathrm{~F}_{3}$ and $\mathrm{F}_{4}(1240-220 \mathrm{cP})$ and it decreased sharply while; apparent viscosity patterns in $\mathrm{F}_{2}, \mathrm{~F}_{3}$ and $\mathrm{F}_{4}$ were much closer to each other and decreased gradually. The high viscosity pattern of $F_{1}$ could be due to the higher proportion and the functionalities of potato starch and barley flour and its $\beta$-glucan. The reduction of apparent viscosity pattern of $F_{2}, F_{3}$ and $F_{4}$ may be due to the reduced proportion of potato and barley flour during formulation (Table 1).

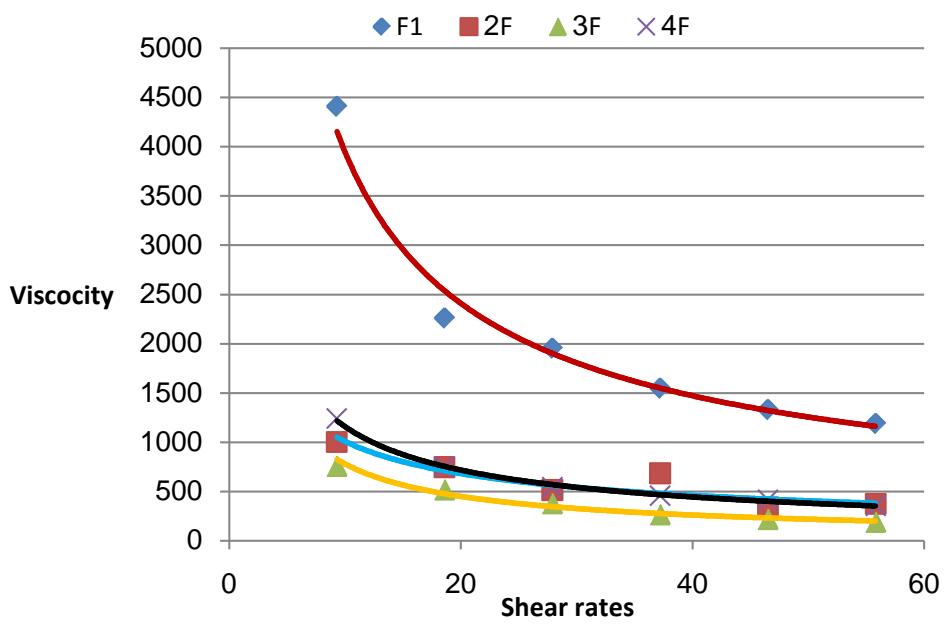

Figure 2. Viscosity of the resultant soup samples at different shearing rates. 
In soup making, viscosity is an index of thickness [52]. Potato flour was used as thickening agents to provide the desirable body and viscosity to the soup mix [53]. $\beta$-glucan has a lower or equal ability to increase viscosity as xanthan, guar gum, locust bean gum and Arabic gum. The good viscosity forming properties make $\beta$-glucans potential alternatives as thickening agents in different food applications [54] [55].

The functional properties of pulse proteins play an important role in food formulation and processing and have been exploited in the preparation and development of soups; such functional properties include solubility, water and fat binding capacity and foaming [33].

\subsubsection{Rehydration Ratio (RR)}

The rehydration properties, rehydration rate, and rehydration capacity are important characteristics of many products, related to their later preparation for consumption [56]. The rehydration capacity was used as a quality characteristic of the dried product [57] expressed in the rehydration rate-RR [58]. When the dried foods reconstituted, it must show acceptable textural, visual, and sensory characteristics, while the rehydration time is minimized [59] [60].

Figure 3 represents the rehydration ratio (RR) of the dried vegetarian mix. Data in Figure 3 proved that supplementation with legumes significantly affected the RR. Where, supplementation with lentil $\left(\mathrm{F}_{2}\right)$ and green pea $\left(F_{3}\right)$ significantly increased the $R R\left(4.38 \pm 0.02^{\mathrm{a}}, 4.34 \pm 0.14^{\mathrm{a}}\right)$ respectively compared to $\mathrm{F}_{1}\left(2.96 \pm 0.04^{\mathrm{C}}\right)$. While, supplementation with chickpea $\left(F_{4}\right)$ significantly reduced the RR where, it recorded the lowest RR $\left(3.19 \pm 0.04^{\mathrm{b}}\right)$ compared to $\mathrm{F}_{2}$ and $\mathrm{F}_{3}$.

From the above mentioned data about RR, it could be stated that the best RR was achieved when supplementation with lentil take place and this is may be due to the lower $a_{\mathrm{w}}$ and water content of $\mathrm{F}_{2}$ compared to $\mathrm{F}_{1}$ and $\mathrm{F}_{4}$ as displayed in Table 4. Jokić et al. [56] mentioned that the products with a high rehydration capacity are tastier and retain their fresh appearance.

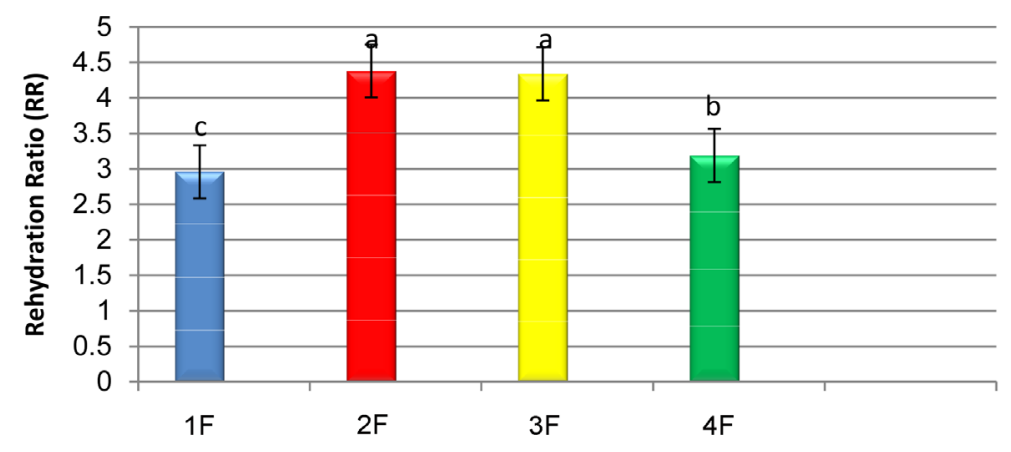

Figure 3. Rehydration ratio (RR) of the dried vegetarian mixtures.

\subsection{Sensory Evaluation of Prepared Soup Samples}

Sensory evaluation is considered to be a valuable tool in solving problems involving food acceptability. It is useful in product improvement, quality maintenance and more important in a new product development [61] [62]. Dry soup should possess desired quality, representing the dominant flavor and aroma of the ingredients used. It is desirable that the product be free from off flavor, off taste, unacceptable aroma and faulty texture [53]. Sensory quality attributes of the resultant soup supplemented with legumes are presented in Table 6. Data in

Table 6. Sensory quality attributes of the resultant soup.

\begin{tabular}{|c|c|c|c|c|c|c|}
\hline Treatments & Taste (10) & Color (10) & Flavor (10) & $\begin{array}{l}\text { Thickness and } \\
\text { Appearance (10) }\end{array}$ & $\begin{array}{c}\text { Dissolution Rate } \\
\text { (10) }\end{array}$ & $\begin{array}{c}\text { Overall } \\
\text { Acceptability (50) }\end{array}$ \\
\hline $\mathrm{F}_{1}$ & $8.30 \pm 1.16^{\mathrm{ab}}$ & $9.40 \pm 0.84^{\mathrm{a}}$ & $8.70 \pm 0.95^{\mathrm{ab}}$ & $8.55 \pm 1.01^{\mathrm{a}}$ & $8.40 \pm 1.17^{\mathrm{a}}$ & $43.35 \pm 3.97^{\mathrm{ab}}$ \\
\hline $\mathrm{F}_{2}$ & $9.10 \pm 0.91^{\mathrm{a}}$ & $9.45 \pm 0.50^{\mathrm{a}}$ & $9.10 \pm 0.84^{\mathrm{a}}$ & $9.25 \pm 0.72^{\mathrm{a}}$ & $9.05 \pm 0.76^{\mathrm{a}}$ & $45.85 \pm 2.71^{\mathrm{a}}$ \\
\hline $\mathrm{F}_{3}$ & $7.90 \pm 1.44^{\mathrm{b}}$ & $8.50 \pm 0.97^{b}$ & $7.80 \pm 1.16^{\mathrm{b}}$ & $8.40 \pm 0.99^{\mathrm{a}}$ & $9.05 \pm 1.01^{\mathrm{a}}$ & $41.65 \pm 3.05^{\mathrm{b}}$ \\
\hline $\mathrm{F}_{4}$ & $8.20 \pm 1.32^{\mathrm{ab}}$ & $8.45 \pm 1.12^{\mathrm{b}}$ & $8.30 \pm 1.15^{\mathrm{ab}}$ & $8.55 \pm 1.30^{\mathrm{a}}$ & $8.80 \pm 0.95^{\mathrm{a}}$ & $42.30 \pm 4.78^{b}$ \\
\hline
\end{tabular}

Values are mean of ten replicates $\pm \mathrm{SD}$, number in the same column followed by the same letter are not significantly different at 0.05 level. 
Table 6 revealed that supplementation with legumes significantly $(\mathrm{p} \leq 0.05)$ affects taste, color, flavor attributes and overall acceptability of the resultant soup samples. But, it had no significant effect on thickness and appearance as well as dissolution rate. Lentil soup $\left(\mathrm{F}_{1}\right)$ recorded the highest score of the quality attributes, in turn, the overall acceptability.

\section{Conclusion}

It could be concluded that the results of this study clearly demonstrated the usefulness of supplementing dried vegetarian soup mixture with lentil, green pea and chickpea as a valuable food addition to enhance nutritional characteristics and technological quality of the resultant soup. Where, they're a reasonable source of protein, Fe and $\mathrm{Zn}$ with good in vitro digestibility and availability, with good stability and extending shelf-life. Along overall sensory quality of the soup samples, it had satisfactory sensory properties. The most valuable addition with the highest acceptability was the lentil one.

\section{Acknowledgements}

Authors would like to thank the Food Technology Research Institute, Agricultural Research Center for ongoing cooperation to support research and that provided facilities necessary to achieve the desired goals of research.

\section{References}

[1] Krejčová, A., Černohorský, T. and Meixner, D. (2007) Elemental Analysis of Instant Soups and Seasoning Mixtures by ICP-OES. Food Chemistry, 105, 242-247. http://dx.doi.org/10.1016/j.foodchem.2006.11.005

[2] Luh, B.S. and Woodroof, J.G. (1975) Commercial Vegetable Processing. The Avi Publishing Company, Inc., Westport.

[3] Osman, M.A., El-Damaty, S., Shaheen, A. and Ibrahim, M.M. (1991) Production of Precooked Dehydrated Soups. Preparation of Beef Meat, Vegetable Soup and Chemical, Sensory and Keeping Quality Evaluations. Egyptian Journal of Food Science, 19, 257-267.

[4] El Wakeel, M.A. (2007) Ultra Structure and Functional Properties of Some Dry Mixes of Food. M.Sc. Thesis, Faculty of Agriculture, Ain Shams University, Cairo.

[5] Rekha, M.N.A., Yadav, R., Dharmesh, S., Chauhan, A.S. and Ramteke, R.S. (2010) Evaluation of Antioxidant Properties of Dry Soup Mix Extracts Containing Dill (Anethum sowa L.) Leaf. Food and Bioprocess Technology, 3, $441-449$. http://dx.doi.org/10.1007/s11947-008-0123-5

[6] Axtell, B. (1992) Some Economic Considerations of Drying. Food Chain, 7, 17-18.

[7] Pandey, M., Anbidi, A.B., Siagh, S. and Singh, R.P. (2006) Nutritional Evaluation of Leafy Vegetable Paratha. Journal of Human Ecology, 19, 155-156.

[8] Ravindran, G. and Matia-Merino, L. (2009) Starch-Fenugreek (Trigonella foenum-graecum L.) Polysaccharide Interactions in Pure and Soup Systems. Food Hydrocolloids, 23, 1047-1053. http://dx.doi.org/10.1016/j.foodhyd.2008.08.010

[9] Kurien, P.P. (1981) Processing of Pulses. Proceedings of the Workshop on Grain Legumes, Protein Foods and Nutrition Development Association of India, Bombay, 68- 77.

[10] Hooda, S. and Jood, S. (2005) Organoleptic and Nutritional Evaluation of Wheat Biscuits Supplemented with Untreated and Treated Fenugreek Flour. Food Chemistry, 90, 427-435. http://dx.doi.org/10.1016/j.foodchem.2004.05.006

[11] AOAC (2005) Association of Official Analytical Chemist. Official Methods of Analysis. 18th Edition, Washington DC.

[12] James, C.S. (1995) General Food Studies. In: Analytical Chemistry of Foods, Blachie Academic and Professional, London, New York, Tokyo, Chapter 6, 135.

[13] Akeson, W.R. and Stahmann, A. (1964) A Pepsin Pancreatin Digest Index of Protein Quality. Journal of Nutrition, 83, 257-261.

[14] Kiers, J.L., Nout, M.J.R. and Rombouts, F.M. (2000) In Vitro Digestibility of Processed and Fermented Soya Bean, Cowpea and Maize. Journal of the Science of Food and Agriculture, 80, 1325-1331. http://dx.doi.org/10.1002/1097-0010(200007)80:9<1325::AID-JSFA648>3.0.CO;2-K

[15] Cadden, A.M. (1988) Moisture Sorption Characteristics of Several Food Fibers. Journal of Food Science, 53, 11501155. http://dx.doi.org/10.1111/j.1365-2621.1988.tb13550.x

[16] McGurie, R.G. (1992) Reporting of Objective Color Measurements. HortScience, 27, 1254-1255. 
[17] Brookfield Manual (1998) Brookfield Manual Operating Instruction. No. M/98-211-B0104. Brookfield Engineering Laboratories Inc., Middleborough.

[18] Krokida, M.K. and Marinos-Kouris, D. (2003) Rehydration Kinetics of Dehydrated Products. Journal of Food Engineering, 57, 1-7. http://dx.doi.org/10.1016/S0260-8774(02)00214-5

[19] Wang, R., Zhang, M., Mujumdar, A.S. and Sun, J.C. (2009) Microwave Freeze-Drying Characteristics and Sensory Quality of Instant Vegetable Soup. Drying Technology, 27, 962-968. http://dx.doi.org/10.1080/07373930902902040

[20] Roy, F., Boye, J.I. and Simpson, B.K. (2010) Bioactive Proteins and Peptides in Pulse Crops: Pea, Chickpea and Lentil: A Review. Food Research International, 43, 432-442. http://dx.doi.org/10.1016/j.foodres.2009.09.002

[21] Adsule, R.N. (1996) Food and Feed from Legumes and Oil Seeds. In: Nwoloko, E. and Smartt, J., Eds., Food and Feed from Legumes and Oil Seeds, Chapman and Hall Publisher, 84-110.

[22] Shah, H.U., Khan, U.L., Alam, S., Shad, A.A., Iqbal, Z. and Parveen, S. (2011) Effect of Home Cooking on the Retention of Various Nutrients in Commonly Consumed Pulses in Pakistan. Sarhad Journal of Agriculture, 27, 279-284.

[23] Jokanović, M.R., Jovicevic, D., Jepic, A.N. and Vujicic, B.L. (2006) Suitability of Some Green Pea (Pisum sativum L.) Varieties for Processing. Acta Periodica Technologica, 37, 13-20. http://dx.doi.org/10.2298/APT0637013J

[24] Dietary Reference Intakes (DRI) (2005) Dietary Reference Intakes for Energy, Carbohydrate. Fiber, Fat, Fatty Acids, Cholesterol, Protein, and Amino Acids (Macronutrients). The National Academies Press, Washington DC. www.nap.edu

[25] Cámara, F., Amaro, M.A., Barberá, R. and Clemente, G. (2005) Bioaccessibility of Minerals in School Meals: Comparison between Dialysis and Solubility Methods. Food Chemistry, 92, 481-489. http://dx.doi.org/10.1016/j.foodchem.2004.08.009

[26] Yip, R. (2001) Present Knowledge in Nutrition. In: Bowman, B.A. and Russell, R.M., Eds., Present Knowledge in Nutrition, ILSI Press, Washington DC, 311-328.

[27] Hambidge, M. (2000) Human Zinc Deficiency. Journal of Nutrition, 130, 1344S-1349S.

[28] Salgueiro, M.J., Zubilaga, M.B., Lysionek, A.E., Caro, R.A., Weill, R. and Boccio, J.R. (2002) The Role of Zinc in the Growth and Development of Children. Nutrition, 18, 510-519. http://dx.doi.org/10.1016/S0899-9007(01)00812-7

[29] DellaVallea, D.M., Thavarajahb, D., Thavarajah, P., Vandenbergc, A. and Glahna, R.P. (2013) Lentil (Lens culinaris L.) as a Candidate Crop for Iron Biofortification: Is There Genetic Potential for Iron Bioavailability? Field Crops Research, 144, 119-125. http://dx.doi.org/10.1016/j.fcr.2013.01.002

[30] Mindel, E. (2000) Vitaminová bible pro 21. století. Euromedia Group, Knižní klub, Prague.

[31] Spill, M.K., Birch, L.L., Roe, L.S. and Rolls, B.J. (2011) Serving Large Portions of Vegetable Soup at the Start of a Meal Affected Children’s Energy and Vegetable Intake. Appetite, 57, 213-219. http://dx.doi.org/10.1016/j.appet.2011.04.024

[32] Bilgiçli, N., Elgün, A., Nur Herken, E., Türkera, S., Ertaşa, N. and İbanog`lu, Ş. (2006) Effect of Wheat Germ/Bran Addition on the Chemical, Nutritional and Sensory Quality of Tarhana, a Fermented Wheat Flour-Yoghurt Product. Journal of Food Engineering, 77, 680-686. http://dx.doi.org/10.1016/j.jfoodeng.2005.07.030

[33] Boye, J., Zare, F. and Pletch, A. (2010) Pulse Proteins: Processing, Characterization, Functional Properties and Applications in Food and Feed. Food Research International, 43, 414-431. http://dx.doi.org/10.1016/j.foodres.2009.09.003

[34] Clemente, A., Shanchez-Vioque, R., Vioque, J., Bautistab, J. and Millin, F. (1998) Effect of Cooking on Protein Quality of Chickpea (Cicer arietinrum) Seeds. Food Chemistry, 62, 1-6. http://dx.doi.org/10.1016/S0308-8146(97)00180-5

[35] Gargallo, S., Calsamiglia, S. and Ferret, A. (2006) Technical Note: A Modified Three-Step in Vitro Procedure to Determine Intestinal Digestion of Proteins. Journal of Animal Science, 84, 2163-2167. http://dx.doi.org/10.2527/jas.2004-704

[36] Vijayaraghavan, K. (1981) Pulses Nutritional Considerations, Grain Legumes: Agronomy and Crop Improvement Processing and Storage, Marketing and Nutrition. Proceedings of the Workshop, New Delhi, January 1981, 115.

[37] Luo, Y., Xie, W. and Cui, Q. (2010) Effects of Phytase, Cellulase, and Dehulling Treatments on Iron and Zinc in Vitro Solubility in Faba Bean (Vicia faba L.) Flour and Legume Fractions. Journal of Agricultural and Food Chemistry, 58, 2483-2490. http://dx.doi.org/10.1021/jf903275w

[38] Sandström, B. (1992) Dose Dependence of Zinc and Manganese Absorption in Man. Proceedings of the Nutrition Society, 51, 211-218. http://dx.doi.org/10.1079/PNS19920031

[39] Hemalatha, S., Platel, K. and Srinivasan, K. (2007) Bioavailability. Influence of Heat Processing on the Bioaccessibility of Zinc and Iron from Cereals and Pulses Consumed in India. Journal of Trace Elements in Medicine and Biology, 21, 1-7. http://dx.doi.org/10.1016/j.jtemb.2006.10.002

[40] Roos, Y.H. (1997) Water in Milk Products. In: Fox, F.P., Ed., Advanced Dairy Chemistry: Lactose, Water, Salts and 
Vitamins, 2nd Edition, Vol. 3, Chapter 8, UCC, Ireland, 303-346.

[41] Chirife, J., Buera, M. and Labuza, T.P. (1996) Water Activity, Water Glass Dynamics and the Control of Microbiological Growth in Foods. Critical Reviews in Food Science and Nutrition, 36, 465-513. http://dx.doi.org/10.1080/10408399609527736

[42] Sunyoto, M. and Futiawati, R. (2012) The Influence of Full Cream Milk Powder Concentration on the Characteristics of “Rasi” Instant Cream Soup. Journal of Agricultural Science and Technology, 2, 1218-1231.

[43] Hall, G.M. (1997) Methods of Testing Protein Functionality. Blackie Academic and Professional, London, Tokyo, and New York, 187-189.

[44] Kilcast, D. and Subramaniam, P. (2000) The Stability and Shelf-Life of Food. Woodhead Publishing Limited and CRC Press LLC, Boca Raton, Washington DC.

[45] Raitio, R., Orlien, V. and Skibsted, L.H. (2011) Storage Stability of Cauliflower Soup Powder: The Effect of Lipid Oxidation and Protein Degradation Reactions. Food Chemistry, 128, 371-379. http://dx.doi.org/10.1016/j.foodchem.2011.03.038

[46] Bonazzi, C. and Dumoulin, E. (2011) Quality Changes in Food Materials as Influenced by Drying Processes. In: Tsotsas, E. and Mujumdar, A.S., Eds., Product Quality and Formulation, Wiley-VCH Verlag GmbH and Co. KGaA, Vol. 3, Chapter 1.

[47] Eskin, N.A.M. and Rebinson, D.S. (2001) Food Shelf Life Stability. CRC Press, Washington, 5-28.

[48] Fellows, P. (2000) Processing Technology Principles and Practice. 2nd Edition, Woodhead Publishing Limited and CRC Press LLC, Washington DC.

[49] Sudha, M.L., Eipson, S.W., Khanum, H., Madhava Naidu, M. and Venkateswara Rao, G. (2013) Effect of Normal/Dehydrated Greens on the Rheological, Microstructural, Nutritional and Quality Characteristics of paratha-An Indian Flat Bread. Journal of Food Science and Technology, Published Online June 2013, Springer.

[50] Ibanoglu, S. and Ibanoglu, E. (1998) Rheological Characterization of Some Traditional Turkish Soups. Journal of Food Engineering, 35, 251-256. http://dx.doi.org/10.1016/S0260-8774(98)00016-8

[51] Antonio, G.C., Faria, F.R., Takeiti, C.Y. and Park, K.J. (2009) Rheological Behavior of Blueberry. Ciênc Tecnology Aliment Campinas, 29, 732-737. http://dx.doi.org/10.1590/S0101-20612009000400006

[52] Ikegwu, O.J., Oledinma, N.U., Nwobasi, V.N. and Alaka, I.C. (2009) Effect of Processing Time and Some Additives on the Apparent Viscosity of "Achi” Brachystegia eurycoma Flour. Journal of Food Technology, 7, 34-37.

[53] Abeysinghe, C.P. and Illepruma, C.K. (2006) Formulation of an MSG (Monosodium Glutamate) Free Instant Vegetable Soup Mix. Journal of the National Science Foundation of Sri Lanka, 34, 91-95.

[54] Dawkins, N.L. and Nnanna, I.A. (1995) Studies on Oat Gum [(1 $\rightarrow 3,1 \rightarrow 4)-\beta$-D-glucan]: Composition, Molecular Weight Estimation and Rheological Properties. Food Hydrocolloids, 9, 1-7. http://dx.doi.org/10.1016/S0268-005X(09)80188-4

[55] Lyly, M., Salmenkallio-Marttila, M., Suortti, T., Autio, K., Poutanen, K. and Lahteenmaki, L. (2004) The Sensory Characteristics and Rheological Properties of Soups Containing Oat and Barley $\beta$-Glucan before and after Freezing. LWT-Food Science and Technology, 37, 749-761. http://dx.doi.org/10.1016/j.lwt.2004.02.009

[56] Jokić, S., Mujić, I., Martinov, M., Velić, D., Bilić, M. and Lukinac, J. (2009) Influence of Drying Procedure on Colour and Rehydration Characteristic of Wild Asparagus. Czech Journal of Food Science, 27, 171-177.

[57] Velić, D., Planinić, M., Tomas, S. and Bilić, M. (2004) Influence of Airflow Velocity on Kinetics of Convection Apple Drying. Journal of Food Engineering, 64, 97-102. http://dx.doi.org/10.1016/j.jfoodeng.2003.09.016

[58] Lewicki, P.P. (1998) Some Remarks on Rehydration of Dried Foods. Journal of Food Engineering, 36, 81-87. http://dx.doi.org/10.1016/S0260-8774(98)00022-3

[59] Sanjuan, N., Simal, S., Bon, J. and Mulet, A. (1999) Modelling of Broccoli Stems Rehydration Process. Journal of Food Engineering, 42, 27-31. http://dx.doi.org/10.1016/S0260-8774(99)00099-0

[60] García-Pascual, P., Sanjuán, N., Melis, R. and Mulet, A. (2006) Morchella esculenta (Morel) Rehydration Process Modeling. Journal of Food Engineering, 72, 346-353. http://dx.doi.org/10.1016/j.jfoodeng.2004.12.014

[61] Kramer, A. and Twigg, B.A. (1974) Quality Control for the Food Industry. 3rd Edition, AVI. Inc., Westport.

[62] Singh-Ackbarali, D. and Maharaj, R. (2014) Sensory Evaluation as a Tool in Determining Acceptability of Innovative Products Developed by Undergraduate Students in Food Science and Technology at the University of Trinidad and Tobago. Journal of Curriculum and Teaching, 3, 10-27. http://dx.doi.org/10.5430/jct.v3n1p10 
Scientific Research Publishing (SCIRP) is one of the largest Open Access journal publishers. It is currently publishing more than 200 open access, online, peer-reviewed journals covering a wide range of academic disciplines. SCIRP serves the worldwide academic communities and contributes to the progress and application of science with its publication.

Other selected journals from SCIRP are listed as below. Submit your manuscript to us via either submit@scirp.org or Online Submission Portal.
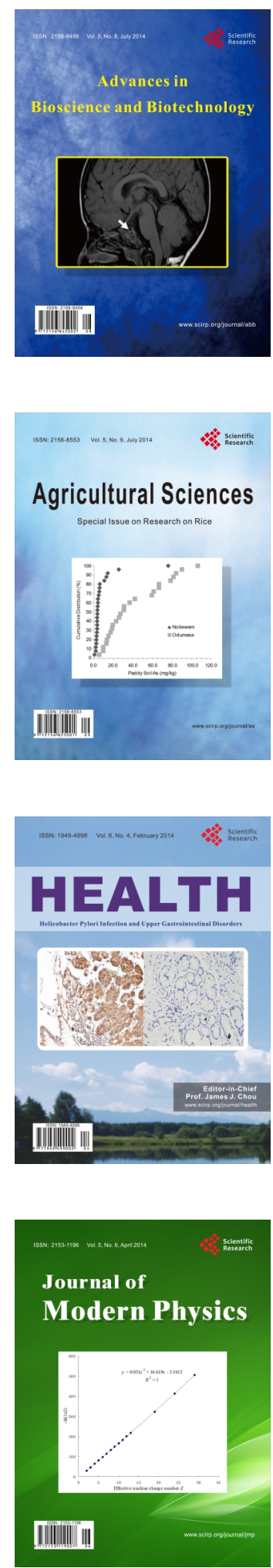
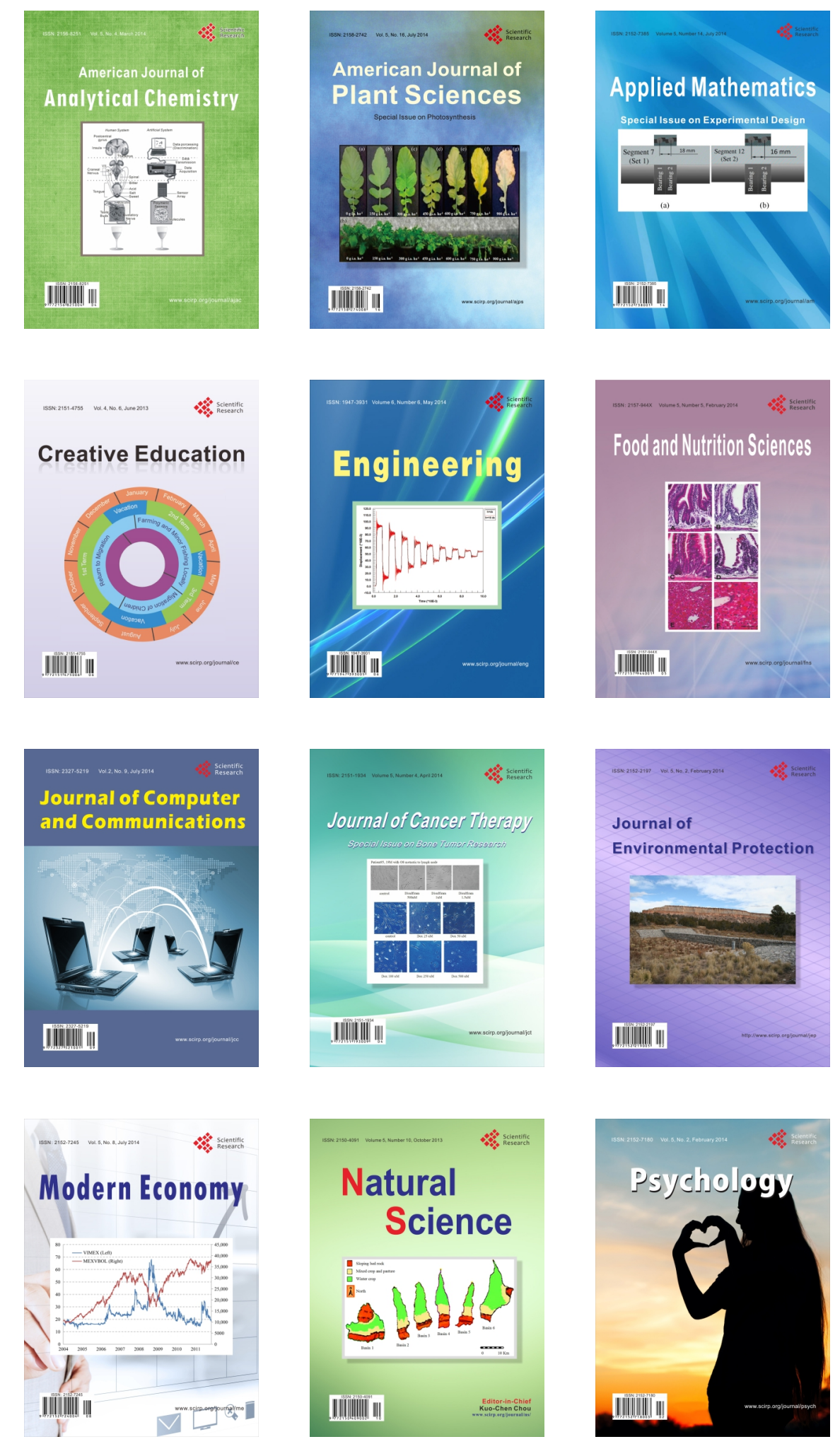